
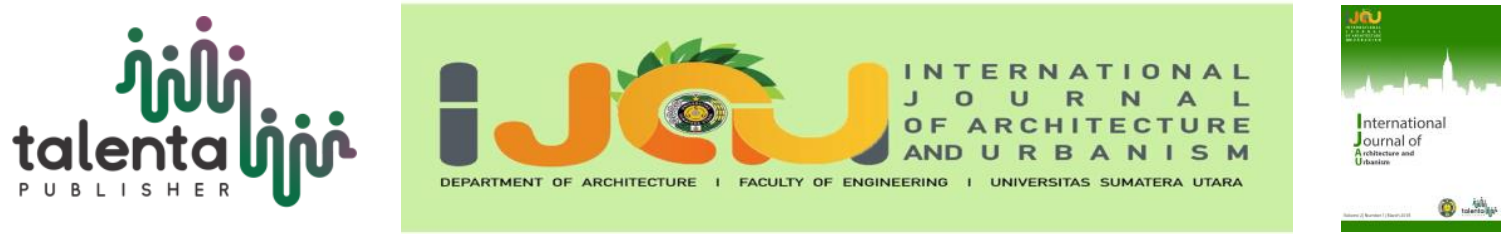

\title{
Sibisa Toba Samosir (Bioclimatic Architecture)
}

\author{
Hajar Suwantoro $^{1^{*}, \text { Teuku Ichwan Rudhie }}{ }^{1}$ \\ ${ }^{I}$ Department of Architecture, Universitas Sumatera Utara, Medan, Indonesia
}

\begin{abstract}
Lake Toba is one of the ten most priority developing tourism destinations in Indonesia, as for 2019 President Joko Widodo targets one million Lake Toba visitors. Toba region strategic location, which surrounds Lake Toba, in addition to the variety of existing natural tourism and culture, become an attraction to the visitor. But, the facilities in this area tend to be an imbalance of what was targeted by the government. The planning of Sibisa Toba Samosir Business Hotel is expected to fulfill lodge accommodation to domestic or international tourists who come over to Lake Toba business activity. Tropical climate potential with the combination of daylight, wind, and rainfall can be a consideration in design. Design approach which initiates bioclimatic architecture can be an eco-friendly building. The sustainable design also can reduce energy usage in all buildings needs aspects.
\end{abstract}

Keyword: Lake Toba, tourism destination, tropical climate

\section{Introduction}

Hotel is defined as a public establishment offering travelers, against payment, two basic service accommodation and catering [3]. The hotel is one type of accommodation that uses part or all of the for lodging services, food and beverage providers and other for the general public that is managed commercially and meets the established requirements In government decisions. However, as the development of the era of hotel functions not only as a means to stay but also serves as a venue for conferences, wedding receptions, seminars, workshops, national deliberations and other such activities that provide complete facilities and infrastructure. Hotels have an important role for a country both for tourism and industry and development. Business in a broad sense is a general term describing an activity and institution that produces goods and services in daily life [1], business is all activity and effort to make a profit by providing the goods and services needed for the economic system, some produce goods while others provide services [2].

North Sumatra is one of the provinces in Indonesia which consists of 25 districts, one of them is Toba Samosir Regency. This regency is one tourist area that has been long enough known by

*Corresponding author at: Department of Architecture, Faculty of Engineering, Universitas Sumatera Utara,

Jalan Perpustakaan Gedung J07, Medan 20155, Indonesia

E-mail address: hsuwantoro@gmail.com 
foreign tourists and domestic tourists because it has a stunning natural beauty of Lake Toba and also some traditional cultural sites typical Batak. Additionally, in line with Nawicita President Jokowi, the Ministry of Tourism of the Republic of Indonesia established Lake Toba as one of 10 priority destinations to be developed in Indonesia. The location of Toba Samosir's strategic district, which surrounds Lake Toba, coupled with the many natural and cultural attractions that lie within it, becomes an attraction for tourists [4].

To anticipate the arrival of domestic and foreign tourists to the Lake Toba area in business activities, it is necessary supporting facilities such as accommodation for a place to stay, one of which is a business hotel that provides complete facilities for business meetings as well as machines, a comfortable temporary residence. PardameanSibisa village is the most potential area with a business hotel. The construction of a business hotel in this area is supported by using a Bioclimatic theme by applying buildings that pay attention to local climate that is environmentally friendly and has beauty/aesthetics (venustas), Strength (Firmitas), and usefulness/function (Utility) is good.

\section{Literature Review}

\subsection{Terminology}

The title of this final assignment is "Sibisa Toba Samosir Business Hotel. Hotel is defined a public establishment offering travelers, against payment, two basic service accommodation and catering [3], business then simply a system that produces goods and service to satisfy the needs of our society [5]. Toba Samosir One of 33 regencies in North Sumatra. Sibisa Toba Samosir Business Hotel: An accommodation with supporting facilities for businessman located in Sibisa Village Toba Samosir District.

\subsection{Comparative study of similar functions}

Sheraton Amsterdam Airport Hotel is a hotel located right near Schiphol Airport Amsterdam, The Netherlands. Located on Schiphol Boulevard Street, 101,118 BG is a 4-star hotel offering direct access to the Airport and is only a 20-minute drive from Amsterdam. The hotel has 407 rooms equipped with soundproof to muffle the noise generated by the activities of the airport (Figure 1). 


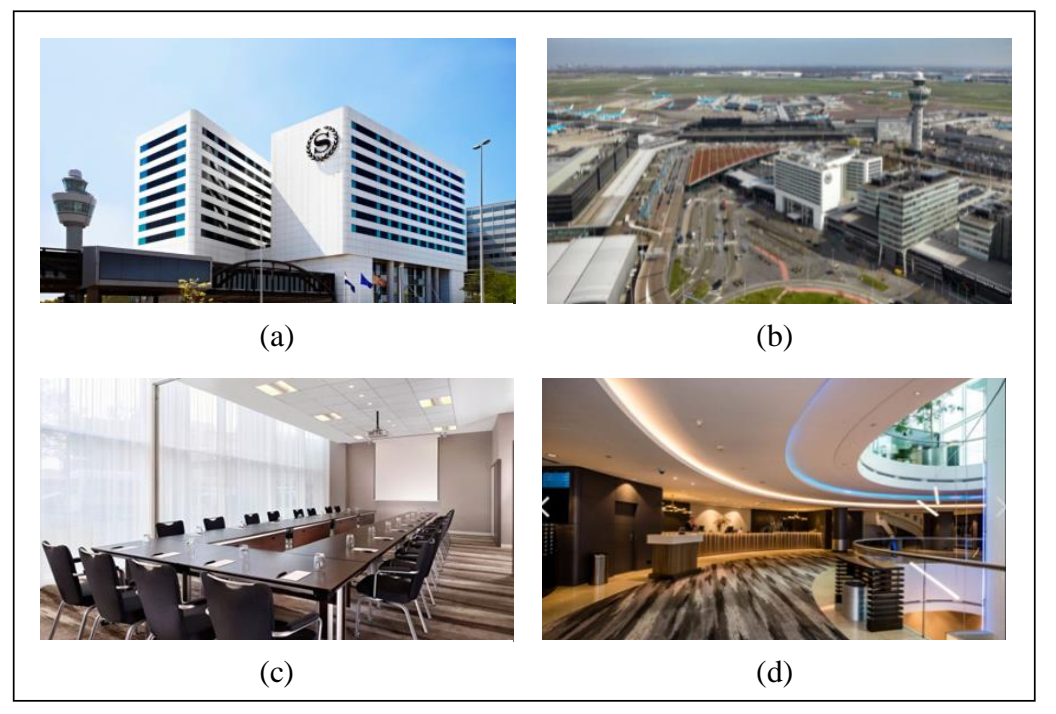

Figure 1. (a) Sheraton Amsterdam Airport Hotel, (b) The Sheraton Amsterdam Airport Hotel looks over the top, (c) Meeting Room Sheraton Amsterdam Airport Hotel, (d) Lobby Sheraton Amsterdam Airport Hotel

(Source: Google Earth and author 2018)

\subsection{Theme Elaboration}

Architecture is the art and science of designing buildings. In a broader sense, the architecture includes designing and building the overall built environment, ranging from the macro level of urban planning, urban design, landscape architecture, to the micro level of building design, furniture design, and product design. Bioclimatic comes from a foreign language Bioclimatology. Bioclimatology is the study of the relationship between climate and life, particularly the effect of climate on the health activity of living things [6].

So based on the above explanation, bioclimatic architecture is an approach that directs the architect to get the completion of the design by considering the relationship between the architectural form with its environment about the climate of the area. The end, the resulting is also influenced by the local culture, and this will affect the expression that will be displayed from a building. Otherwise, the bioclimate approach will reduce dependence on not energy sources.

\subsection{Comparative Study of Architecture of Similar Themes}

The tower built in 1992 is the work of architect Kenneth Yeang, who serves as IBM headquarters in Subang Jaya, Kuala Lumpur, Malaysia. This building is a High-tech building, which has 15 floors. The modern single-tower is the result of a 10-year-old architect Kenneth Yeang's research on the principles of high-rise building design. Three parts of the structure consisting of a raised green base, ten floors of office space surrounded by garden balconies, outer wall hangings as shadows, and a spectacular sun-roofed peak. Typical columns on each support the installation of solar panels, further reducing energy consumption by cooling buildings using natural ventilation, secondary skin, and air conditioning (Figure 2). 


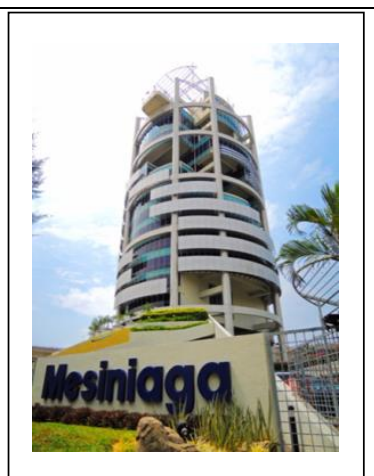

Figure 2. Tower of Mesiniaga

(Source: Google Earth)

Yeang calls his approach the "tall bioclimatic building" that provides energy-sensitive climate control, including the use of green elements, aerations, and natural lighting to examine bioclimatic architecture for high-rise buildings in tropical climates. And the numerous awards of the Mesiniaga Tower are increasingly exciting to continue that rare study. Yeang's awareness in digging high bioclimatic building aims to reduce costs by suppressing energy consumption and developing benefits for users by providing ecological values.

\section{Methodology}

Site selection method us is an area is a National Strategic Area of development of Lake Toba Tourism Area. Strengthening the idea of design by tracing information and data that support both architectural and non-architectural through various libraries and media as a material consideration in solving design problems. The development of the design idea poured into the analysis and synthesis.

\section{Result and Discussion}

\subsection{Project Description}

Sibisa Business hotel design location, Toba Samosir located in the village of Pardamean Sibisa, Ajibata District, Toba Samosir (Figure 3). 


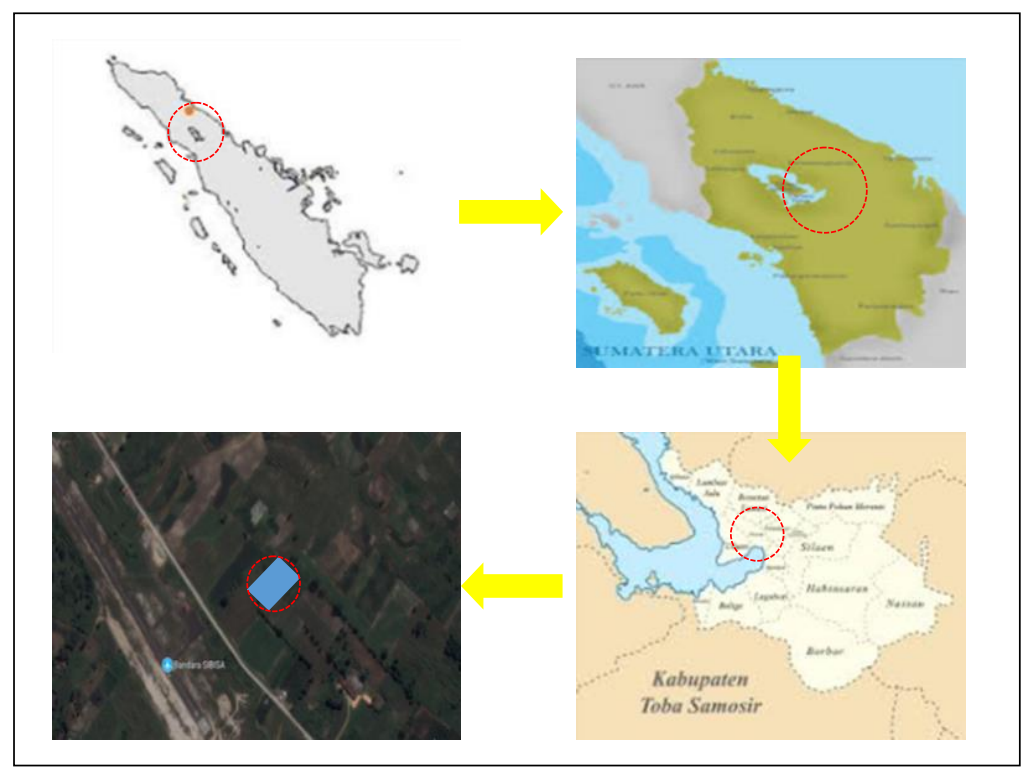

Figure 3. Location of Design

(Source: Google Map)

The design site of Sibisa Toba Samosir Business Hotel located in PardameanSibisa Village, Ajibata district, about $11 \mathrm{~km}$ from Ajibata crossing port. The site has an area of 1.6 hectares with relatively flat contour conditions and is a corn plantation of maize plantations. The footpath is surrounded by a cornfield and directly faces Sibisa Airport (Figure 4).

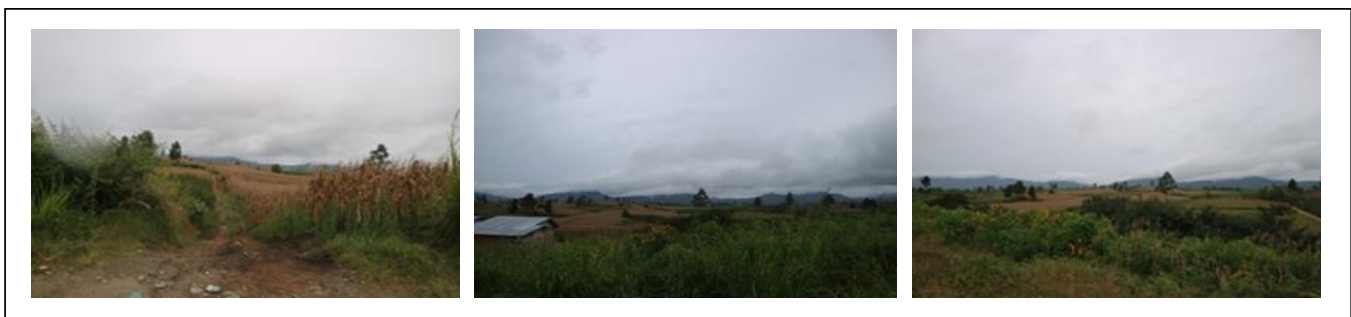

Figure 4. Site Design Conditions

\subsection{Concept of Exterior Space Design / Tread}

The of outdoor space design, the hotel building is in the middle of the site so it can be reached easily. On the front of the hotel, there is VIP parking, on the right side of the hotel, there is fourwheel drive and bus parking lot, on the left side there is a parking area for employees (Figure 5). 


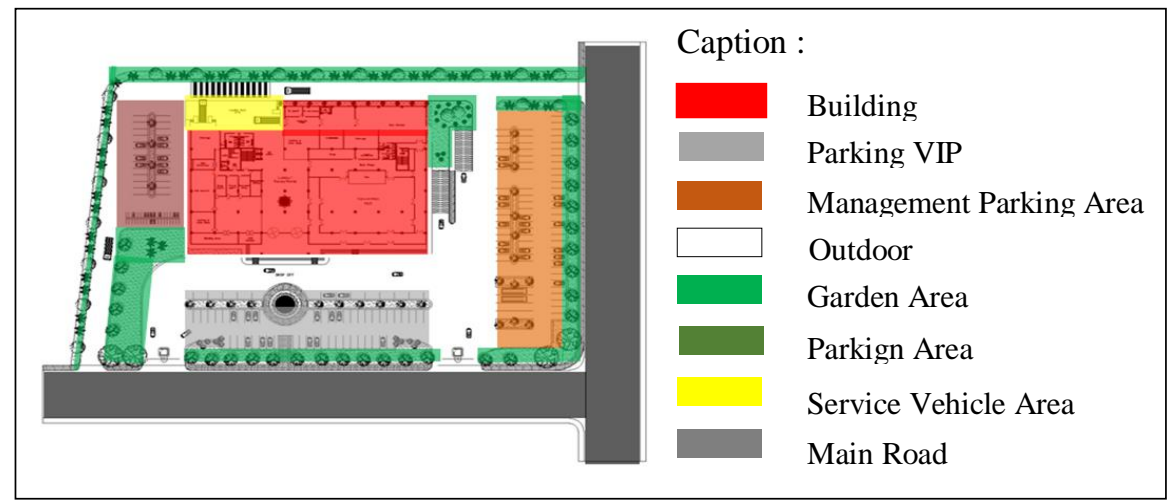

Figure 5. Tread Design Concept

\subsection{Circulation Site}

The entrance of visitors' vehicles through the main and exit through the exit on the east side of the site. Line managers and service vehicles designed around the site, enter through the south door and exit through the east door site (Figure 6).

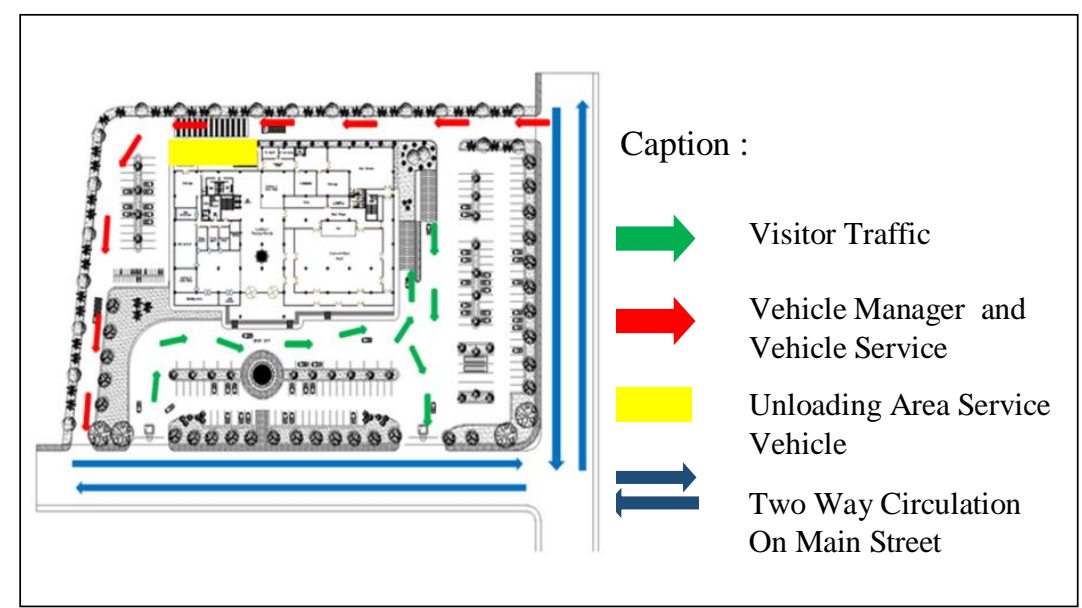

Figure 6. Circulation Site

\subsection{The Concept of Period and Display}

The basic concept of the building of a square shape with a rectangular combination on the floor of the building tower and there are pieces that serve as a direct sun barrier that is adapted to the concept of Bioclimatic Architecture (Figure 7).

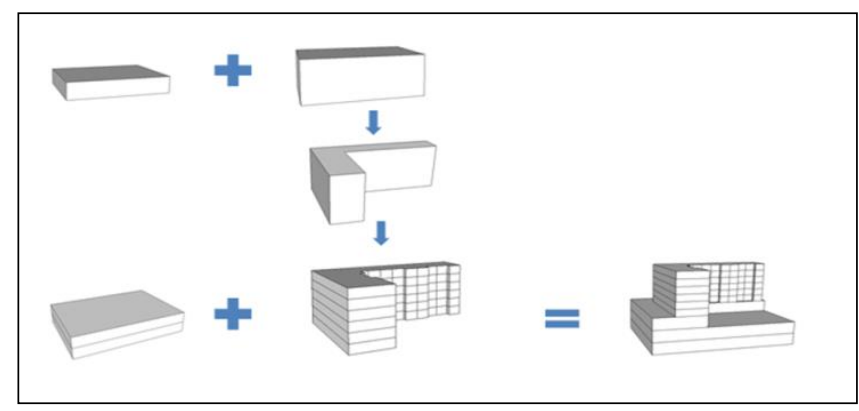

Figure 7. Hotel Building Concept 
The concept of building construction using Secondary Skin on the podium floor as a direct sun block against the building and there are cantilever-cantilever that surrounds each floor of building tower (Figure 8).

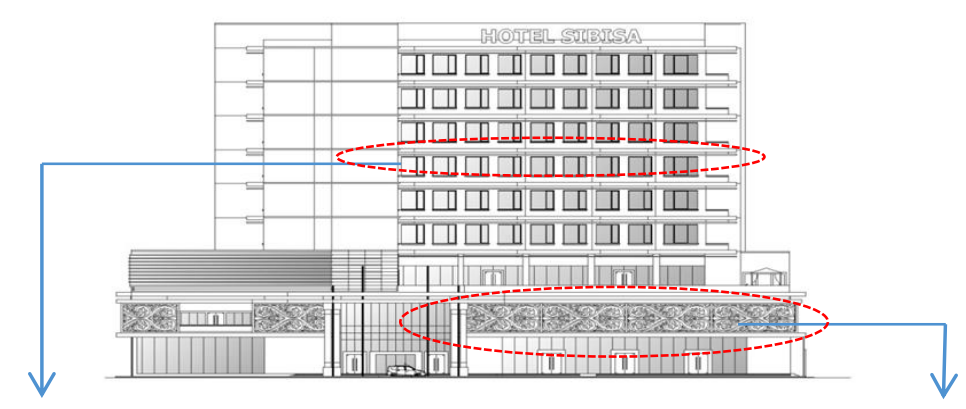

The cantilever located on the floor of the

Secondary Skin by incorporating elements hotel tower serves as a direct sun barrier of Batak Toba, Secondary Skin serves as a against the hotel's rooms. direct sun barrier against the building

Figure 8. Front View Hotel

\subsection{Architecture Design}

The design of the hotel business sibisa attached in the form of photos includes exterior and interior (Figure $9 \&$ Figure 10).

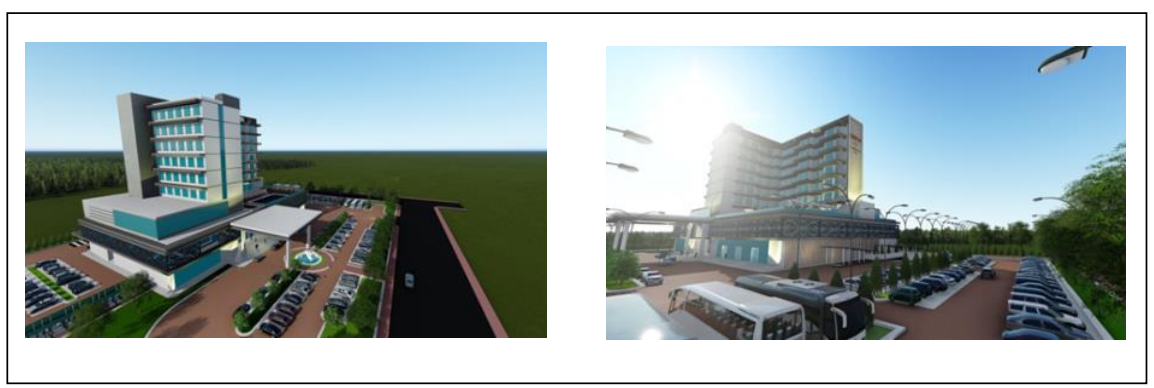

Figure 9. Sibisa Toba Samosir Business Building Exterior

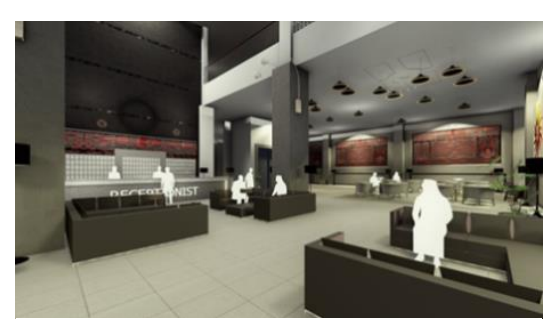

(a)

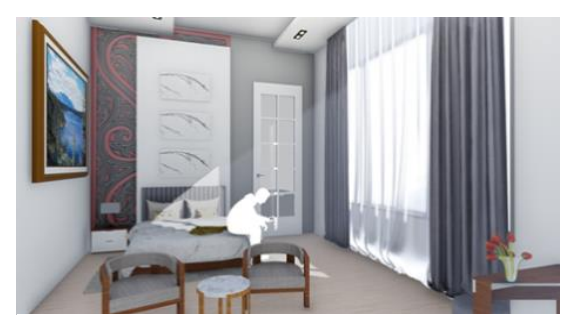

(b)

Figure 10. Sibisa Toba Samosir Business Building Interior (a) Lobby (b) Room 


\section{Conclusion}

Sibisa Toba Samosir Business Hotel is a business hotel located in Toba Samosir district precisely in Pardamean Sibisa village about $11 \mathrm{~km}$ from Ajibata airport. In the of PardameanSibisa, there is an airport that is no longer functioning so that with Lake Toba as one of the priority destinations it is possible to re-activate Sibisa Airport. Sibisa Bussiness Hotel located right across the airport so that the hotel also has a function as an airport hotel that is expected to make suggestions for visitors of local and foreign tourists who visit the lake region Toba. The hotel uses a bioclimatic architectural design approach so, hopefully, that the building of Sibisa Business Hotel can be an environmentally friendly building as well as the climate of the area as well as towards the visitors who visit this hotel.

\section{Acknowledgment}

This journal as a requirement to obtain a Bachelor of Engineering degree in Architecture Department, Universitas Sumatera Utara.

\section{REFERENCES}

[1] I. H. Amirullah. Pengantar Bisnis, Edisi Pertama, Grahailmu, Yogyakarta. 2005.

[2] D. L. Kurtz and L. E. Boone. Contemporary Business. Cengage Learning. 2008.

[3] F. R. Lawson. Hotels and resorts: planning, design and refurbishment. ButterworthHeinemann Ltd, 1995.

[4] F. R. E. P. Pardede and I. B. Suryawan. Strategi Pengelolaan Kabupaten Samosir Sebagai Daya Tarik Wisata Alam Di Provinsi Sumatera Utara. Jurnal Destinasi Pariwisata ISSN, 2338, 8811. Vol. 01 No. 01. 2013.

[5] C. H. Tan. Singapore financial and business sourcebook. NUS Press. 2002.

[6] K. Yeang, A. Balfour, and I. Richards. Bioclimatic skyscrapers. Ellipsis London, Limited. 1994. 